\title{
INTERNATIONAL ROUND TABLE ON SOCIAL HISTORY
}

The Round Table met at the University of Pittsburgh on February 19 and 20. 1976. The subject of this meeting was the Reorganization of Work and Workers' Responses. 1900-1920. The participants were: Patrick Fridenson. Maurice Levy-Leboyer. Daniel Mothé. Aimée Moutet and Michelle Perrot from France, Gerald Feldman. Leopold Haimson, James Laux. David Montgomery. Charles Tilly, Louise Tilly, Peter N. Stearns, and Joseph L. White from the United States. Dieter Groh and Jurgen Kocka from Germany, James Hinton. Sidney Pollard, Edward P. Thompson and Dorothy Thompson from England, and Gwyn A. Williams from Wales.

Four papers were distributed in advance of the meeting to serve as bases for discussion: Aimée Moutet. "Les origines du systeme Taylor" en France: Le point de vue patronal (1907-1914)." P. Fridenson. "Les ouvriers Français face a l'introduction du Taylorisme." D. Montgomery, "Whose Standards? Workers and the Reorganization of Production in the United States. 1900-1920." and D. Groh, "Some Thoughts on the Relationship between the Intensification of Work and Industrial Conflict in Organized Capitalism in Germany (18\%. 1914)." In addition to these texts, brief commentaries on the papers and on the subject before the Round Table were written by Perrot. Laux. Stearns. Hinton, Mothé and Feldman.

On the morning of Thursday, February 19, the participants assembled in the lounge of the new Law School Building, where all the sessions were held. Perrot chaired the morning session and introduced the subject by posing a series of questions concerning the nature of scientific management, the motivations of employers in introducing it on the eve of the war, the structural characteristics of industry at the time, and the problems of ideology and power involved in the new methods of work organization. In the discussion which followed, Pollard deliniated the points of continuity between older managerial practices and the new, while Kocka and Laux specified the industrial sectors in which scientific management and other comparable reforms were most widespread. The role of the state in the mobilization of war industries and in combatting union struggles against the new methods was emphasized by Thompson and Haimson.

The topics of the morning's discussion blended easily with those which were raised in the afternoon. the questions of workers' responses and industrial conflicts set off by managerial innovations. Montgomery chaired this session. The contrast between the reactions of newcomers from agricultural backgrounds, who saw some opportunity for themselves in the new methods, and skilled craftsmen. whose position was fundamentally threatened, was noted by Stearns. Pollard and Mothé. Montgomery argued that to pose the question simply in terms of workers' responses to managerial innovations was misleading, because major industrial conflicts of the epoch arose from the interaction of the thrust of organized workers for greater social power and the attempts of employers and engineers to increase their control over the workplace. Thompson and Perrot stressed the need to cast one's intellectual net still more broadly. to encompass all efforts to incorporate workers into the national state on the eve of the war. and even more during it. and the corresponding emergence of strong internationalistic revolutionary minorities among the workers. Hinton contended that the politicization of labor processes themseives was at the heart of this latter phenomenon. 
Saturday morning. while Charles Tilly presided. Williams carried the final points of the previous day's discussion into an analysis of the experience of the metal workers of Turin in their factory councils' movement between 1915 and 1921. Older syndicalist traditions were rapidly transformed under wartime conditions, as the more skilled workers formed councils which sought initially to supervise every aspect of factory life. then to move their activities out of the factory base to questions of the family, education, and national politics. Questions of the interaction of work social life generally were elaborated upon by Haimson, Laux, Pollard, and Hinton. Perrot. Feldman. Kocka and Fridenson, and Groh explored the impact of these questions, and especially the workers' own concern with production and efficiency and the evolution of shop delegates' movements in France. Germany and England, on the ideological controversies within the socialist movement, at the time that it was torn in two.

The Round Table proved to be very valuable from three points of view. First by bringing together experts in the histories of several different advanced industrial countries it made it possible for the participants to develop useful generalizations about the locations and characteristics of managerial innovations on the eve of the war, on the basis of economic developments rather than national peculiarities. Second, both the papers circulated in advance and the discussion clarified the nature of workers' responses. such as turnover, strikes, delegates' movements. the types of workers who participated in such activities and those who acquiesced in the changes or even welcomed them, and the ways in which conflicts over work practices were reflected in the rhetoric and demands of workers' movements. Finally, for most of the participants at least. the discussion made it clear that managerial reform cannot be treated as the independent variable which explains the industrial conflict of the epoch. Employers' strategies, state policies, and workers' movements need to be set in a broader context of social and political developments to be understood. On the other hand, the questions on which the Round Table focused do involve one very important aspect of the period's evolution. The discussions made clear to the participants just what could and what could not be learned from the analysis of this subject.

\author{
David Montgomery \\ University of Pittsburgh
}

The 9th Annual Pacific Northwest Labor History Association Conference met in Seattle from May 13-15, 1976. The program included sessions on the Protection of Woman Workers. The Western Federation of M:nere Acian-Amprican Workers Radiral I ahor in the Northwest. Labor in the 1930s. Defending the Wobblies, and Labor Conflict. For further intormation contact the Association c/o Washington Federation of Teachers. 2366 Eastlake Ave. East. No. 209, Seattle. Washington 98102. 